\title{
Oral Health Status Among Schoolchildren: Does Partnership With School of Dentistry Make A Difference?
}

\author{
Sri Widiati \\ Department of Dental Public Health and Preventive Dentistry \\ Faculty of Dentistry, Universitas Gadjah Mada \\ Yogyakarta, Indonesia \\ E-mail: sriwidiati@yahoo.com \\ Received September 15, 2010; Accepted December 18, 2010
}

\begin{abstract}
The purpose of this study was to evaluate whether the partnership between 26 primary schools with the Faculty of Dentistry, Universitas Gadjah Mada, during the past 12 years improved oral health status of the schoolchildren. A sample survey was carried out, involving 106 fifth and sixth graders from 9 schools which have been participating in the partnership and 90 schoolchildren from non-participating schools. They were examined by trained dental students. Oral health status was represented by OHI-S and DMF-t measurement. Knowledge and attitude of oral health were measured using structured questionnaires. The study indicated that the means of OHI-S and DMF-t among schoolchildren participating in the partnership were 0.11 and 0.01 lower respectively compared to those of their counterparts, although the differences were not significant statistically. The knowledge and attitude among schoolchildren in the partnership were 2.49, 4.18, and 3.86 higher, all were highly significant $(p<0.001)$. Path analyses showed that the partnership reduced OHI-S and DMF-t with an overall path coefficients -0.086 and -0.076 respectively. Although knowledge was associated with DMF-t and attitude with OHI-S, there were other unmeasured variables which were more strongly associated with oral health status of the schoolchildren.
\end{abstract}

Keywords:Partnership with school of dentistry, oral health status, KAP survey.

\section{Introduction}

Schoolchildren are considered to be an important target group for various health education and promotion activities ${ }^{1}$, with the hope that these will result in an improved healthy lifestyle which lasts for a lifetime. Dental diseases are the most prevalent chronic conditions among schoolchildren, although the trend is decreasing in developed countries $^{2}$. If left untreated, dental diseases are progressively destructive of teeth, gums and bony supporting structures ${ }^{3}$. Most dental diseases, especially periodontal diseases and dental caries, are preventable through the practice of appropriate dental and oral hygiene care, optimal use of fluoride and lower frequency of sugar consumption ${ }^{4}$.

Schools have played an important role in the delivery of dental services to schoolchildren from the earliest days of school health. School dental health program has been implemented in Indonesia since $1951^{5}$. However, the intensity of the program varies. Activities, suchasfluoridation ofschoolwatersupplies, fluoride application, nutrition education, toothbrushing in school with tooth paste, dental cleaning and scaling, screening and referral for treatment, and provision for dental treatment on school premises were implemented. The comprehensive dental health promotion, prevention and treatment 
need resources which were only partially met by the primary health centers and health sector in general. Faculty of Dentistry, Universitas Gadjah Mada, has been collaborating with 26 primary schools in Depok Subdistrict, Yogyakarta, one of the smallest provinces in Indonesia, in the past 12 years. The emphasis of the school dental health collaborating program has been on dental health promotion and disease prevention through education, screening, and primary care.

The partnership between the Faculty of Dentistry, Universitas Gadjah Mada, and primary schools in Yogyakarta has never been evaluated. Hypothetically, primary schools implementing the collaborative program with the school of dentistry show improved knowledge, attitude and practice with regards to dental health, among the schoolchildren. The comprehensive program should also decrease periodontal diseases and dental caries among the schoolchildren.

\section{Subjects and Methods}

There were 106 schoolchildrens (fifth and sixth graders) randomly selected from among 9 participating primary schools, and 90 students from non-participating schools, comparable in grades, size of the schools and access to health care facilities. Oral health status was measured using OHI-S (Oral Hygiene Index Simplified) developed by Green and Vermillion ${ }^{6}$ and DMF-t examinations, carried out by trained dental students. Knowledge about dental health promotion and diseases prevention was measured using 18 test items (possible scores range from 0 to 18). Attitude to dental health was measured using 18 questions based on a 4-point Likert scale.

Direct comparisons of oral and dental health status (OHI-S and DMF-t), knowledge and attitude to dental health between schoolchildren from participating and those from non-participating schools were conducted using independent t-tests. Causal modeling to explore the roles of knowledge and attitude on oral and dental health status was developed using path analyses.

\section{Results and Discussion}

The findings of the study showed that oral hygiene (OHI-S) and caries prevalence (DMF-t) among schoolchildren from schools in partnership with Faculty of Dentistry, Universitas Gadjah Mada were lower compared to those from schools not participating in the partnership. However, the differences between the two groups were not statistically significant (Table 1).

Table 1. Oral health status among schoolchildren participating and not participating in the partnership with Faculty of Dentistry, Universitas Gadjah Mada.

\begin{tabular}{cccc}
\hline & \multicolumn{3}{c}{$\begin{array}{c}\text { Partnership with Faculty of Dentistry } \\
\text { Universitas Gadjah Mada }\end{array}$} \\
\cline { 2 - 4 } $\begin{array}{c}\text { Oral } \\
\text { Health }\end{array}$ & $\begin{array}{c}\text { Children from } \\
\text { participating } \\
\text { schools }\end{array}$ & $\begin{array}{c}\text { Children from } \\
\text { non-participating } \\
\text { schools }\end{array}$ & $\begin{array}{c}\mathbf{t} \\
\text { (p value) }\end{array}$ \\
\hline OHI-S & 1.096 & 1.201 & -1.084 \\
& & & $(0.280)$ \\
DMF-t & 3.280 & 3.227 & -1.523 \\
& & & $(0.129)$ \\
\hline
\end{tabular}

Knowledge and attitude concerning oral and dental health were better among school children from participating schools, compared to those from non-participating ones. The differences were statistically significant (Table 2).

Path analyses suggested that partnership with Faculty of Dentistry, Universitas Gadjah Mada significantly improved knowledge and attitude to oral and dental health, however only attitude of the schoolchildren reduced OHI-S (Figure 1). Meanwhile, only knowledge about oral and dental health reduced DMF-t (Figure 2).

Overall, path coefficient for OHI-S was -0.086 , indicating that $99.26 \%$ of variation in $\mathrm{OHI}-\mathrm{S}$ is explained by variables not measured in this study. Dental health education programs, which have had significant impact on knowledge and attitude toward oral and dental health, were not linked to changes in behavior and improvement in oral health status ${ }^{7}$. 
A study in Korea indicated that although dental health education program significantly improved knowledge and behavior with regards to dental health, it failed to increase perceived self-efficacy, sensitivity, severity and importance of dental care ${ }^{8}$.

Table 2.Knowledge and attitude toward oral and dental health among schoolchildren participating and not participating in the partnership with Faculty of Dentistry, Universitas Gadjah Mada.

\begin{tabular}{lccc}
\hline & \multicolumn{3}{c}{$\begin{array}{c}\text { Partnership with Faculty of Dentistry } \\
\text { Gadjah Mada University }\end{array}$} \\
\cline { 2 - 4 } & $\begin{array}{c}\text { Children from } \\
\text { participating } \\
\text { schools }\end{array}$ & $\begin{array}{c}\text { Children from } \\
\text { non-partici- } \\
\text { pating schools }\end{array}$ & $\begin{array}{c}\mathbf{t} \\
\text { (p value) }\end{array}$ \\
\hline Knowledge & 12.25 & 9.76 & $\begin{array}{c}6.684 \\
\text { Attitude }\end{array}$ \\
& 62.08 & 57.90 & $\begin{array}{c}0.001) \\
(0.001)\end{array}$ \\
& & & \\
\hline
\end{tabular}

Path coefficient for DMF-t was -0.076, which means that $99.42 \%$ of variation in DMF-T is not explained by variables in this study. Socio-demographics, such as maternal education and other variables not measured in this study, were associated with caries experience among schoolchildren from Southern Brazil $^{1}$. A 6-year oral health education program for primary schoolchildren did not significantly reduce DMF-t, although it did improve dietary habit, proper use of topical fluoride, and care index ${ }^{9}$.

\section{Conclusions}

Partnership between primary schools in Depok Subdistrict with Faculty of Dentistry, Universitas Gadjah Mada improved knowledge and attitude concerning oral and dental health, but failed to decrease $\mathrm{OHI}-\mathrm{S}$ and DMF-t indicating that more comprehensive interventions are needed to

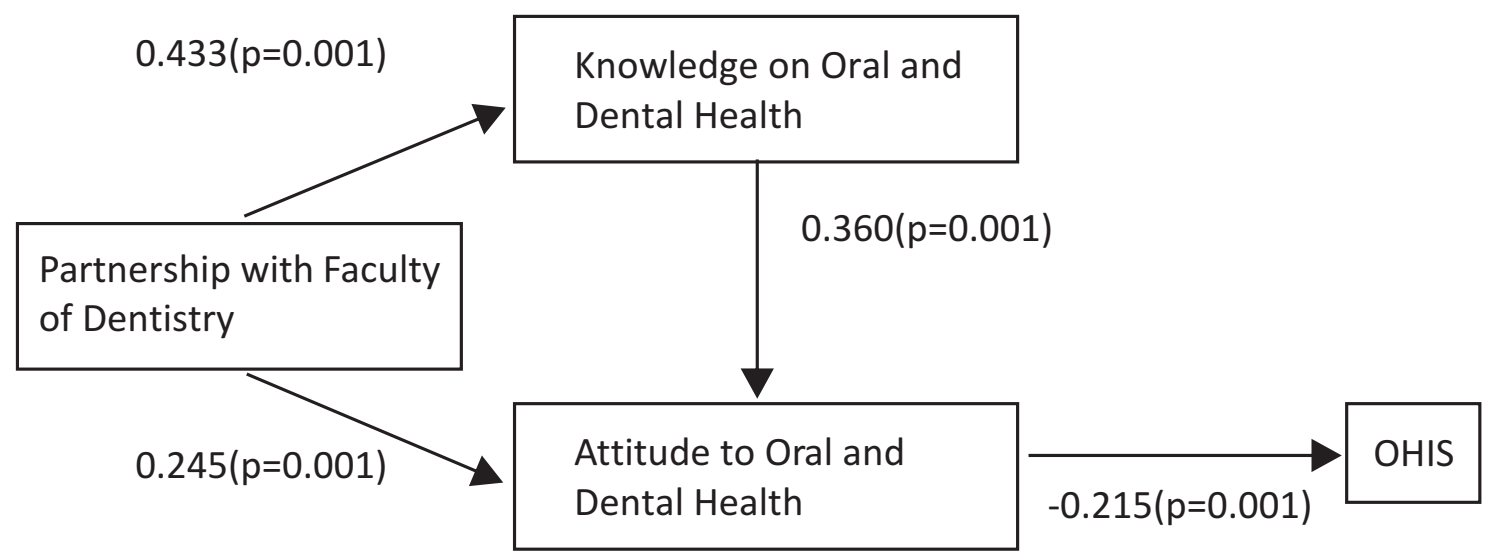

Figure 1. Causal modeling of partnership, knowledge, attitude and OHI-S.

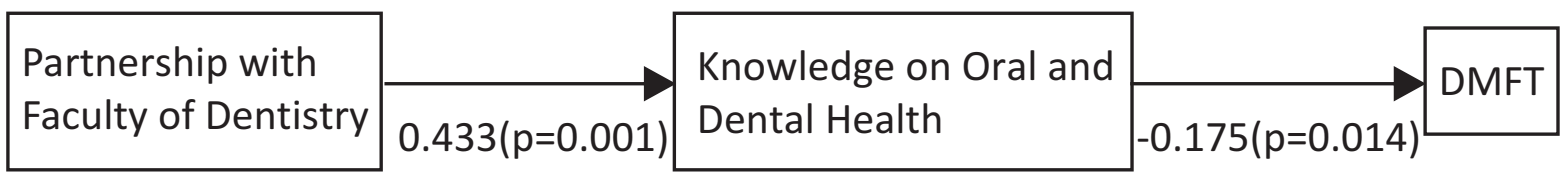

Figure 2. Causal modeling of partnership, knowledge about oral and dental health and DMF-t. 
enhance oral hygiene and prevent dental caries. These interventions include boosting self-efficacy and healthy habits such as proper tooth brushing, fluoride application, less sugar consumption and early dental diagnosis and treatment, preferably provided in the schools.

\section{References}

1. Allukian M. 1993.Forging the future: the public health imperative.Am J Pub Health 83: 655-60.

2. Auad SM, Waterhouse PJ, Nunn JH, Moynihan PJ.2009.Dental caries and its association with sociodemographics, erosion and diet in schoolchildren from Southeast Brazil.Ped Dent 31:229-35.

3. Kocher T, Konig J, Dzierzon U, Sawaf H, Plagmann HC. 2000. Disease progression in periodentally treated and untreated patients- a retrospective study.J ClinPeriodontol 27: 866-72.
4. Jain P, Pundir RK. 2009. Strategies to prevent and treat dental caries and periodontal disease.J Pharmacy Res 2: 1223-8.

5. Departemen Kesehatan. 2000. Pedoman Upaya Pelayanan Kesehatan Gigi dan Mulut di Puskesmas, Jakarta.

6. Greene JC, Vermillion JR. 1960. The oral hygiene index: a method for classifying oral hygiene status. JADA 61: 172-9.

7. Bentley JM, Cormier P, Oler J. 1983. The rural dental health program: the effect of a schoolbased, dental health education program on children's utilization of dental services. Am J Public Health 73: 500-5.

8. Ahn HY, Yi G. 2010. Application of dental health program for elementary school children.J Korean Acad Child Health Nurs 16: 49-55.

9. Vannobergen J, Declerck D, Mwalili S, Martens L. 2004. The effectiveness of a 6-year oral health education programme for primary schoolchildren.Community Dent Oral Epidemiol 32: 173-182. 